\title{
THE RETABLO-FAÇADE AS TRANSPARENCY: A STUDY OF THE FRONTISPIECE OF SAN FRANCISCO, LIMA
}

\section{HUMBERTO RODRÍGUEZCAMILLONI}

The retablo-façade, a translation into stone of the gilded wood altarpiece, reached a high point of artistic expression in Lima during the seventeenth century. As an impressive display of decorative splendour, it constitutes one of the greatest achievements of Peruvian colonial art. The main portal of San Francisco (fig. 1), designed by the Portuguese architect Constantino de Vasconcelos around 1657 and executed by his assistant Manuel de Escobar between 1672 and 1674, is a masterpiece of the type and marked a decisive moment in the development of colonial church façades.

While recognizing the originality of the colonial work, previous studies have often emphasized the "dependency" on Spanish models for its inspiration. An examination of the documentary evidence and comparison with extant monuments of the seventeenth century in Lima and Cuzco, however, shows that closer links may be established with earlier colonial works and with designs found in a number of non-Hispanic European pattern books which are known to have been widely circulated in the artistic circles throughout the viceregal territories. This study investigates some of these specific sources in detail, the extent of their relationship to the San Francisco portal, and the very important but hitherto neglected aspect of its central iconographic theme which is a key to the understanding of the entire composition.

The most complete account on the construction of the present church of San Francisco is found in the book, Templo de N. Grande Patriarca San Francisco de la Provincia de los Doce Apóstoles de el Perú en la Ciudad de los Reyes, written by Fray Miguel Suárez de Figueroa and Juan de Benavides and published in Lima in $1675 .^{1}$ In it, we are told

1 Fray Miguel Suárez de Figueroa, Templo de N. Grande Patriarca, San Francisco de la Provincia de los doze Apóstoles de el Perú en la Ciudad de los Reyes amuinado, restaurado, y engrandecido de la providencia Divina, published together with Visita y declaración que hizo el P. Fr. Juan de Benavides, ministio legal y honesta persona del Santo Tribunal de la Inquisición y sacristán mayor del Convento Grande de N.P.S. Francisco, en la residencia del Rmo. P.D. 
that this church replaced an earlier structure that had suffered damage beyond repair during an earthquake in 1655 and which had collapsed the following year. This publication included a contemporary engraving by Juan de Benavides showing a perspective view of the exterior of the monastic complex, including the design of the main portal or frontispiece of the church (fig. 2). A comparison between the engraving, the description in the text and the frontispiece as it survives today shows no major discrepancy. The towers flanking the fronstispiece do not match the engraving, however, since the original two-story belfries were reduced in their height following the earthquakes of 1687 and 1746 (fig. 3). ${ }^{2}$

The general scheme corresponds to that of the twin-tower or harmonic façade, with the main portal occupying the central portion. Proportions have been worked out carefully so that the width of the portal is exactly one-third the total width of the facade; and its height is exactly twice its width. A distinct mannerist trait is the heavy rustication of the towers derived from Italian or French sources like Serlio or Del'Orme; and mannerist tendencies are also seen in the tension resulting from the contrast between the overweighted massive towers and the almost delicate stonework of the fronstipiece in between. More sculptural than architectural in its extensive use of surface ornament, the main portal actually combines figure sculpture with a rich repertoire of decorative forms accentuated by the play of light and shade.

Constantino de Vasconcelos, who provided the plans for the new church begun in 1657, is also credited with the design of the frontispiece, even though it was only completed posthumously by Manuel de Escobar. ${ }^{3}$ There is no reason why this authorship should be questioned, as Harold E. Wethey once did, since Vasconcelos was a maestro

Luis Zerbela, padre perpetuo de la Provincia de Santiago, y de todas las del Perú, del tiempo que fue comisario general de ellas, Lima, 1675.

2 Cf. Humberto Rodríguez-Camilloni, "Dl Conjunto Monumentâl de San Frañisisto de Lima en los Siglos xVI y xuII," Boletin del Centro de Investigaciones Históricas y Estéticas, Universidad Central de Venezuela, Facultad de Arquitectura y Urbanismo, No. 14, septiempre 1972, pp. 31-60.

3 Vasconcelos died in 1668 and he was buried in the apse of San Francisco. His obituary is recorded in the archives of the parish church of San Marcelo in Lima, Libro de Funeral del Curato de San Marcelo de que es cura el Dr. Pedro Sánchez Vadillo desde primero de enero de 1655, f. 55: "en 23 [de agosto de 1668] entierro mayor en San Francisco de Don Constantino Vasconcelos".

4 Harold E. Wethey, "Franciscan Art in Peru," The Americas, IX, 4, April, 1953, p. 406. 
retablero in addition to being a distinguished architect. Evidence for this is provided by an extant document dated 1662 which shows he designed the retablo for the main altar of the church of San Juan de Dios in Lima (unfortunately now lost). ${ }^{5}$

In typical fashion, from the outset the Franciscan community was divided about the cost of the new church that had been proposed. There were those who wished to observe the original rule of absolute poverty; and others who, clearly wishing to emulate the Dominicans, did not feel as bound. Construction thus proceeded at a slow pace; and Vasconcelos' death in 1668 surely did not help matters any. The following year, however, the principals of the Franciscan Order opted for dispatching Padre Fray Luis de Cervela from the Province of Santiago de Compostela to Lima for the specific purpose of supervising the completion of the work. ${ }^{6}$ Cervela was able to accomplish his mission to perfection in a period of five years (1669-1674), thanks to his energetic administrative direction. In order to reassure the Franciscan friars of the worthiness of the project and the justification of the cost, as a contemporary source tells us, Cervela approached his companions saying: "Be silent, my brothers: Why should we mind the expense, if the church is intended to praise the greatness of Our Lord?" The final arbitrator in this dispute, however, was the Holy Father himself, Pope Clement X (1670-1676), who settled the controversy once and for all by claiming the church of San Francisco as part of his domain, granting it the same indulgences, rights and privileges as his own basilica of San Giovanni in Laterano in Rome. Visual testimony of this act was recorded above the doorway (fig. 4), where a relief depicts the papal coat of arms according to a design that was sent from Rome, which is preserved in the archives of the Lima monastery (fig. 5). ${ }^{\mathrm{s}}$

The fronstispiece itself is divided into three stories symmetrically arranged, in the first story, the doorway is flanked by two pairs of or-

5 Archivo General de la Nación, Lima, Juan Bautista de Herrera, escribano público, prot.1662, f. 632. The contract specifies that two maestros ensambladores, Josef Lorenzo Moreno and Josef Pizarro, were to make the retablo "siguiendo las reglas de la arquitectura que aparecian de manifiesto en la correspondiente planta, suscrita por los obligados y por Don Constantino de Vasconcelos".

6 Benjamín Gento Sanz, San Francisco de Lima, Lima, 1945, pp. 135-149.

7 Fr. Agustín de Barreda, Oración Evangélica y Frmebre Predicada en la Nveua Capilla de Maria Santissima de la Soledad, Lima, 1674, unnumbered f.

8 Gento Sanz, op. cit., pp. 151-152, mentions this drawing, but it is reproduced here for the first time. 
namental columns with corinthian capitals resting on individual pedestals decorated with cherub heads in relief (fig. 6). The shaft of each column presents a spiral striation in its lower third section, and classical fluting in the upper two thirds, with the decoration of a draped female head. These columns (A) are alternated with eight smaller columns (b), which establish a b.A.bb.A.b rhythm at either side. The larger columns are topped by a complete entablature block, where the cornice steps forward and curves upward at the middle to embrace the central niche of the second story containing the statue of the Virgin of the Inmaculate Conception. The frieze is richly decorated with draped heads, ovolos and dentils which intensify the play of light and shade.

In the second story (fig. 7), a third type of column with a zigzag striation in its lower third section is introduced, supported on decorative consols. Four of these columns are used to frame and separate a trinity of niches containing the statue of the Inmaculate Conception in the center, accompanied by the kneeling figures of St. Dominic (to the left) and St. Francis (to the right). This figural group constitutes the iconographic and compositional focus of the façade and, as we shall see later, ties in together with an iconographic theme developed in the interior of the church. The niches themselves have shell tympana that function as halos for the figures and connect with other curvilinear forms leading the eye to the architrave that marks the upper limits of the second story.

At the top, the third story consists of three-dimensional scroll-work which provides an even more intricate play of concave and convex lines and surfaces (fig. 8). Here, once again a broken pediment, echoing the one above the doorway, embraces an oval window which admits light into the raised choir inside the church. The window's frame has a scale-and-tongue motif also found in the niches below; and is flanked by two fluted pilaster-brackets. Finally, a projecting cornice picks up the ascending movement, and is surmounted by a curved balustrade and radiant sun with the monogram of Jesus, insignia of the Patron Saint. The vertical movement initiated by the columns of the first story thus builds up into a crescendo by means of a skillful orchestration of the most varied forms that, in a truly baroque spirit, culminates in an appropiate climax. Adding to this effect is the subordination of the individual parts of the whole, the most pictorial handling of the masses, with pronounced projections of mouldings, broken cornices and the constant movement throughout, which makes the 
eye dance from one level to the next, in a manner that anticipates later architectural developments of the eighteenth century.

The portal of San Francisco has been long recognized as "the first important retablo façade in Lima, and one which possesses great originality in its design as a whole, as well as in the ingenious manipulation of its multiple ornamental devices". ${ }^{9}$ Vasconcelos' design undoubtedly represents a brilliant realization in an evolutionary process that had begun around 1655, with the completion of the main portal of the Cathedral of Lima by Pedro Noguera, who substantially altered the original design of 1626 by Juan Martínez de Arrona (fig. 9) ${ }^{10}$ Noguera's chief contribution consisted in liberating the portal from a strict architectural ordering by introducing a broken curved pediment above the doorway. This pediment, in fact, is made by curving the cornice supported by the corinthian columns of the first story. The opening at the center thus formed is then filled with a decorative niche housing a sculptural figure resulting in a deeper penetration of planes and upward movement toward the second story not found in Arrona's design. This was an early attempt, still timid, but it signaled a new direction in church portal design.

Important architectural developments in the city of Cuzco during the second half of the seventeenth century also need to be considered. Most extant colonial buildings in Cuzco date from after the devastating earthquake of 1650 and many correspond to the great period of reconstruction and prosperity which followed, largely due to the patronage of Bishop Manuel de Mollinedo y Angulo, who coincidentally presided over the dedication of the new Franciscan church in Lima on January 22, 1673. The presence of Vasconcelos in Cuzco has been historically documented; ${ }^{11}$ and he would have had the opportunity to study the existing buildings. The evidence shows that the retablo-façade underwent almost a parallel development in Cuzco and Lima and the two cities became important centers for the spread and interchange of artistic ideas. Most telling, for example, are the main portals of the Cathedral of Cuzco, completed in 1658, and of the 83.

9 Harold E. Wethey, Colonial Architecture and Sculpture in Peru, Cambridge, 1949, p.

10 The original drawing for the frontispiece of the Cathedral of Lima was traced and published by Emilio Harth-Terré, "El Imafronte de la Catedral de Lima," El Arquitecto Peruano, Año V, No. 47, Lima, junio de 1941.

11 Rubén Vargas Ugarte, Ensayo de un Diccionario de Artífices de la América Meridional, 2d. ed., Burgos, 1968, pp. 361.363. 
Jesuit church of La Compañía, designed by the Flemish architect Juan Bautista Egidiano and executed by the famous sculptor Diego Martínez de Oviedo in 1664 (fig. 10). As in the case of San Francisco in Lima, these two portals are essentially conceived as great altarpieces in stone with complexity of architectural planes an rich play of light and shade. The parallel is of course closest between San Francisco and La Compañía, which share many of the same decorative elements and, as I have demonstrated in another study, use very similar proportions for the overall design of the façade, including the twin towers. ${ }^{12}$

I believe it can be convincingly shown that the sources of inspiration for both Cuzco and Lima may have been quite similar, if not the same. The possibilities are always quite varied and numerous, but the great majority appear to correspond to non-Hispanic European sources, such as Flemish, Dutch, French or Italian. A wide range of architectural treatises and pattern books in different languages are recorded in contemporary inventories that show their availability in the Spanish American colonies from the sixteenth century onwards. ${ }^{13}$ Contrary to what is generally believed, cities like Lima and Cuzco not only boasted an international artistic community, but also enjoyed considerable literary activity of their own; and, judging from book orders sent to the Old World, claimed a public who demanded the best and most recent products of Europe's printing presses. ${ }^{14}$ In the end, however, it was the intervention of the genius of the individual artist who, through the process of carefully selecting, synthesizing and reinterpreting these sources would succeed in creating an original masterpiece in its own right. The examples that follow may help to illustrate the nature of this process in the case of the San Francisco portal.

One of the decorative elements frequently repeated on the column shafts and broken friezes consists of a draped female head, sometimes also surrounded by drapery garlands containing fruit. This is a motif associated with Renaissance arabesques; and is often found in architectural drawings by Vredeman Vries (fig. 11). Similarly, the niche

12 Humberto Rodríguez-Camilloni, "Architectural Principles of the Age of Humanism Applied: The Church of San Francisco, Lima," Journal of the Society of Architectural Historians, XXVIII, 4, December, 1969, pp. 235-253.

13 José Torre Revello, "Tratados de Arquitectura utilizados en Hispanoamérica (siglos xvI a xVIII)," Revista Interamericana de Bibliografia, vol. VI, No. 1, Washington, D.C., 1956, pp. 3-24.

14 Cf. Irving A. Leonard, Los Libros del Conquistador, México, 1958; and Ramón Gutiérrez, Nolas para una Bibliografia Hispanoamericana de Arquilectura (1526-1875), Resistencia, 1972. 
frames showing half-disks or scale-and-tongue moldings and denticulated edges are found in designs which appeared in the Dutch edition of Vignola published in Amsterdam in 1642 (fig. 12). The border frets with floral and anthropomorphic motifs recall similar designs by Crispijn de Passe. The miniature lanterns supported by brackets which flank the second story columns (fig. 13), also found next to the belfries at $\mathrm{La}$ Compañia in Cuzco, are closely reminiscent of the crowning element in an architectural design by Jacques Francquart dated 1609 (fig. 14). The intrados of the doorway arch is also richly decorated with floral designs contained in rectangular frames which may be related to drawings by Paul Androuet du Cerceau. Finally, the oval window in the upper story of the fronstispiece (fig. 8) may have been derived from engravings published by Bernardino Radi in Rome in 1618 (fig. 15).

At the same time, as Enrico Marco Dorta once pointed out, ${ }^{15}$ a large percentage of the decorative elements in the San Francisco portal had already found their way during the first half of the seventeenth century into many of the Lima retablos, choir stalls and pulpits. The original sources, however, would have been the same indicated above. For example, the draped female heads and drapery filled with fruit had appeared in 1626 in the choir stalls of the Cathedral of Lima, a famous work by Martín Alonso de Mesa and Pedro de Noguera. The same motif is repeated in the stepped frieze above the columns of the Franciscan portal, in a manner that recalls the formula used above the tribune of c. 1670 in the chapter house of the Augustinian monastery in Lima. Corinthian columns of the same type used in the first story of the San Francisco portal are also found in the retablo of the Inmacu. late Conception inside the Cathedral of Lima (fig. 16), a work originally executed around 1656 and later restored between 1692 and 1697 by the sculptor Diego de Aguirre.

Even closer to the Franciscan frontispiece is the monument erected in Lima in 1666 to celebrate the coronation of King Charles II of Spain (fig. 17). The designer was the Mercedarian Cristóbal Caballero, "renown architect and sculptor," and has survived in a rare engraving signed by P.A. Delhom. ${ }^{16}$ Here may be seen many of the same decora-

15 Enrique Marco Dorta, La Arquitectura Barroca en el Peru, Madrid, 1957, p. 10.

16 This engraving was included in the publication Aclamación y Pendones que levantó la myy noble y coronada Civdad de los Reyes, por el Católico y avgustissimo Rey d. Carlos II deste nombre N.S. con festiva solemnidad el dia 17 de octvbre, Año de 1666, Lima, 1666, a copy of which survives in the Beineke Library, Yale University, New Haven, Connecticut. In 
tive elements already mentioned, in a very similar arrangement. There is an analogous vertical division into three stories, and also a similar alternation of columns of different sizes. Another parallel is the formula of the broken curved pediment, except that here a frame with the royal coat of arms replaces the central niche of the San Francisco portal.

The importance of the Franciscan frontispiece may be measured in terms of its direct or indirect influence on other Peruvian colonial churches. Constantino de Vasconcelos and Manuel de Escobar led the way in a new development of church portal design, the impact of which could still be appreciated more than a century later. The Franciscan portal was the first example of the fully developed retablofaçade in Lima and many of its elements became a part of the sculptural repertoire of church façade designs in the city. During the seventeenth century, the churches of N. Señora de los Desamparados (also built by Escobar in 1669-1672), Santa Rosa de los Padres (1669. 1685), and N. Señora de Copacabana (1700) can be mentioned. The portal of the church of San Agustín, dated 1720 (fig. 18), which may be regarded as the culmination in the development of the retablofaçade in Lima, exhibits spiral columns and an unsurpassed exuberance of expression, but still relies on the Franciscan model for its overall organization.

Outside of Lima, in the northern Peruvian coast, the church of Santa Lucía at Ferreñafe, Lambayeque, of c. 1684-90 (fig. 19), shows again the familiar ornamental motifs that recall the Franciscan portal. Even a small rural chapel like that of San Juan de Villa of c. 1743, located south of the city, exhibits in its façade oval windows and broken curved pediments, though here these elements have undergone a popular interpretation reducing them almost naively to calligraphic signs.

We need now to look closer at the central iconographic theme of the portal of San Francisco, representing the Immaculate Conception standing between Saint Dominic and Saint Francis - not "two Franciscan saints," as Pál Kelemen wrote back in 1951, much to the outrage, no doubt, of the Dominicans (fig. 7). ${ }^{17}$ Figure sculpture is restricted to this group, which occupies a prominent location in the frontispiece. It

the text (p. 13), Caballero is praised in the following terms: "La estampa, que dibujo el bu. rilh se ajusta a la obra, que fue del ingenio y traza del Padre fray Christoval Cavallero, de la orden de nuestra Señora de la Merced, insigne en la arquitectura, y escultura".

17 Pál Kelemen, Baroque and Rococo in Latin America, 2d. ed., New York, 1967, p. 152. 
should be noted that the figures are of polychromed wood of very fine quality and not of stone, as they are commonly described in the art history literature. Their stone-like appearance -especially in black-andwhite photographs - is due to their exposure to the elements and to several layers of pigeon feces, which have already caused considerable damage. This important discovery was made during the elaboration of a restoration project of the monument in which this author was personally involved a few years ago, when traces of blue were found on the Virgin's robe and traces of black on St. Dominic's habit. The implications of this are of considerable interest because clearly another aspect is added to our appreciation of the portal as it was originally conceived. It is also almost certain that the stonework of the rest of the portal would have been originally painted in different colors producing a striking effect, as was the case with a number of Mexican retablofaçades of the eighteenth century. At least one source, Wethey in 1949 , noted that the entire portal had "a yellowish color as the result of numerous coats of paint". ${ }^{18}$

The pairing of St. Dominic and St. Francis in the presence of the Immaculate Conception is not coincidental and surely was meant to celebrate a vision that both saints had shared during their lifetime. While visiting Rome in 1215, on the occasion of the Fourth Lateran Council, St. Dominic had a dream where he saw himself presented by the Virgin to Our Lord, accompanied by a stranger who, like himself, was charged with converting the world. When the next day he noticed St. Francis in a street of the city, he recognized in him the stranger of his dream. He then stopped St. Francis, narrated his vision to him, and embracing him, said: "Let us be comrades, and nothing on earth can prevail against us". ${ }^{19}$ This theme is, in fact, repeated more than once in the interior of the church of San Francisco: first, behind the frontispiece itself, in the bishop's throne of c. 1674 located in the raised choir, where the saints are engaged in their fraternal abrazo (fig. 20); and then again, in the retablo of the main altar (fig. 21). Even though this retablo dates from 1803-1805, it appears to have preserved the iconography of the original altarpiece of the seventeenth century (probably also designed by Vasconcelos), as may be deduced from the reading of contemporary descriptions. ${ }^{20}$

18 Wethey, Colonial Architecture and Sculpture in Peru, p. 82.

19 Cf. Omer Englebert, St. Francis of Assisi, Ann Arbor, 1979, pp. 139-146.

20 Cf. Fr. Pedro Rodríguez Guillén, El Sol y Año Feliz del Perú, Madrid, 1735, pp. 5965. That the Franciscans may have favored this theme even earlier during the seven- 
The idea of the frontispiece as a transparency or preview of the main altar may indeed reflect Vasconcelos' conception, but it may be difficult to prove conclusively today. There is evidence that suggests that this idea may have occured even earlier to the architect Juan Martínez de Arrona, who, when submitting his design for the main portal of the Cathedral of Lima in 1626, explained that its cost would always be justified because "church portals permanently advertise the grandeur of the works found in the interiors and, moreover, give the people the greatest pleasure" ${ }^{21}$ At La Compañia in Cuzco, a contemporary monument that parallels San Francisco in different ways, we can see the same idea fully developed.

The display of the Immaculate Conception in the Franciscan portal must also be understood in the light of the traditional rivalry which existed between the two religious Orders that St. Francis and St. Dominic had founded. The Franciscans, who had always shown a great devotion for the Immaculate Conception, must have rejoiced when she was proclaimed patron saint of the city of Lima on December 8,1654 . The solemn feast that celebrated this event in the Cathedral was highlighted by a spirited homily delivered by the Franciscan Fr. Gonzalo de Herrera that was dedicated to the Archbishop D. Pedro de Villagómez and published a year later under the title: Oración Evangélica que predicaba en la Cathedral de Lima al juramento que hizieron los señores Virrey, Arzobispo, Audiencia, ambos Cabildos y demás de la ciudad, de tener y defender la Concepción Santíssima de Maria el dia de su fiesta.... ${ }^{22}$ Herrera, who was Provincial or head of the Franciscan community when the main portal of his church was comissioned to Vasconcelos in 1657, may have suggested the iconographic theme of the Immaculate Conception, knowing well the idea would have been wholeheartedly endorsed by Archbishop Villagómez.

teenth century is also attested by the fact that it is found once again inside the monastery in one of the smail polychromed retablos that decorate each of the corners of the main cloister (a photograph of which is reproduced in Gento Sanz, op. cit.). These four retablos originally date from 1629 , but were painted and gilded only during the term of Comisario General, Fr. Luis de Cervela (1669-74). The intriguing possibility remains that Vasconcelos himself may have borrowed the central iconographic theme for his frontispiece from the older Franciscan church which collapsed in 1656.

21 Archivo General de la Nación, Lima, Bartolomé de Civico, escribano público, prot. 321, 1626, f. 2651.

22 Cf. Carlos Alberto Romero, "Disturbios religiosos en Lima," Revista Histórica, I, Lima, 1906, pp. $271-287$. 
In contrast, for the Dominicans the mystery of the Inmaculate Conception had always remained a thorny issue, since many members of the Order had been reluctant to accept the dogma of the Virgin without original sin. The Dominican position on this matter had evidently a long history, but it generated several colorful incidents in Lima during the seventeenth century that ultimately forced King Philip IV of Spain to order the unruly friars to begin all their sermons with the invocation: "Blessed and praised be the Most Holy Sacrament of the altar and the Virgin Mary, Our Lady, conceived without original sin from the moment of her conception". ${ }^{23}$ In their Chronicle of Colonial Lima (1640-1697) Josephe and Francisco Mugaburu narrated the incident of January 1, 1663, when a Dominican in charge of the sermon in the Cathedral did not say "...and the Virgin Mary, Our lady, conceived without sin...," causing the outrage of the entire congregation. ${ }^{24}$ The issue was finally put to rest after the chapter celebrated by the Dominicans on July 24,1664, when the Order vowed to honor the Immaculate Conception with a great feast. According to Mugaburu,

...there was a great procession through the streets and plazas of [the] city [on July 30 of the same year. A statue of] Saint Dominic was carried on a gilded wooden litter; [an image of] the Virgin of the Conception from [the church of] Santo Domingo was on a silver litter; all the religious order chanting, 'Without original sin'. Archbishop Don Pedro de Villagómez in pontifical attire, and the cabildo appeared [in the procession] where all the nobility of this city gathered to illuminate [with candles] the Most Holy Virgin. The statue was from the Franciscan monastery, and... it was taken in procession back to San Francisco [church]. ${ }^{25}$

Perfect harmony and close friendship may have been more symbolic than real between Franciscans and Dominicans, but it appears that religious authorities made the point of reminding the friars of this Christian ideal. This meaning was further reinforced through the popular ritual of street processions involving the archbishop himself. Thus, Mugaburu also tells us that

Friday, the 3rd of [October of 1664], at four in the afternoon [the statue of] Saint Francis was taken from its church to the plaza with all the saints

23 Ibid., p. 275 .

24 Josephe and Francisco Mugaburu, Chronicle of Colonial Lima, translated and edited by Robert Ryal Miller, Norman, 1975, p. 76.

25 Jbid, p. 87. 
of the [Franciscan] order. There it awaited [the statue of] Saint Dominic, and the two were taken together to the Cathedral. With great solemnity and with all the accompaniment of his cabildo, the archbishop brought the Holy Sacrament, may it be forever praised, to the new church of San Francisco where it was deposited that afternoon. Everyone attended the vespers, the archbishop, his cabildo, and all the people of this city. ${ }^{26}$

The frontispiece of San Francisco was conceived as a gate of heaven, and provided a fitting backdrop to outdoor ceremonies such as these that played a significant part in the life of the city. George Kubler reminds us that in colonial Peru, nearly one-fourth of the year was consumed in the celebration of the Catholic calendar, where the feasts not only involved all the major events in the geneology and life of Christ, but commemorated also virtually each and every one of the apostles and saints. By this means, the ritual calendar itself became a lengthy catechetical exercise, and the parishioners learned the contents of the New Testament through direct participation in its festivals. ${ }^{27}$ On those frequent occasions, the atrium and plaza in front of the church became an extension of the sacred space of the interior.

San Francisco undoubtedly provides the best architecture of seventeenth century Lima and probably the best architecture of its time in the Americas. The main portal is one masterpiece that demonstrates the validity of this statement and shows that aesthetic ideals in colonial Peru could be crystalized in an artistic work of great originality and exceptional beauty. In the process, the old forms that were imported from Europe were reinterpreted and enriched through new combinations that ensured them a prolonged life for centuries to come. The art and architecture of this period can not be thought of as one debased by intellectual poverty, where mere imitation was the rule. Far from it, this was an age marked by a youthful spirit constantly driven by experimentation and discovery.

26 Ibid, p. 89.

27 George Kubler, "The Quechua in the Colonial World", Handbook of South American Indians, vol. 2, Washington, D.C., 1946, p. 406. 


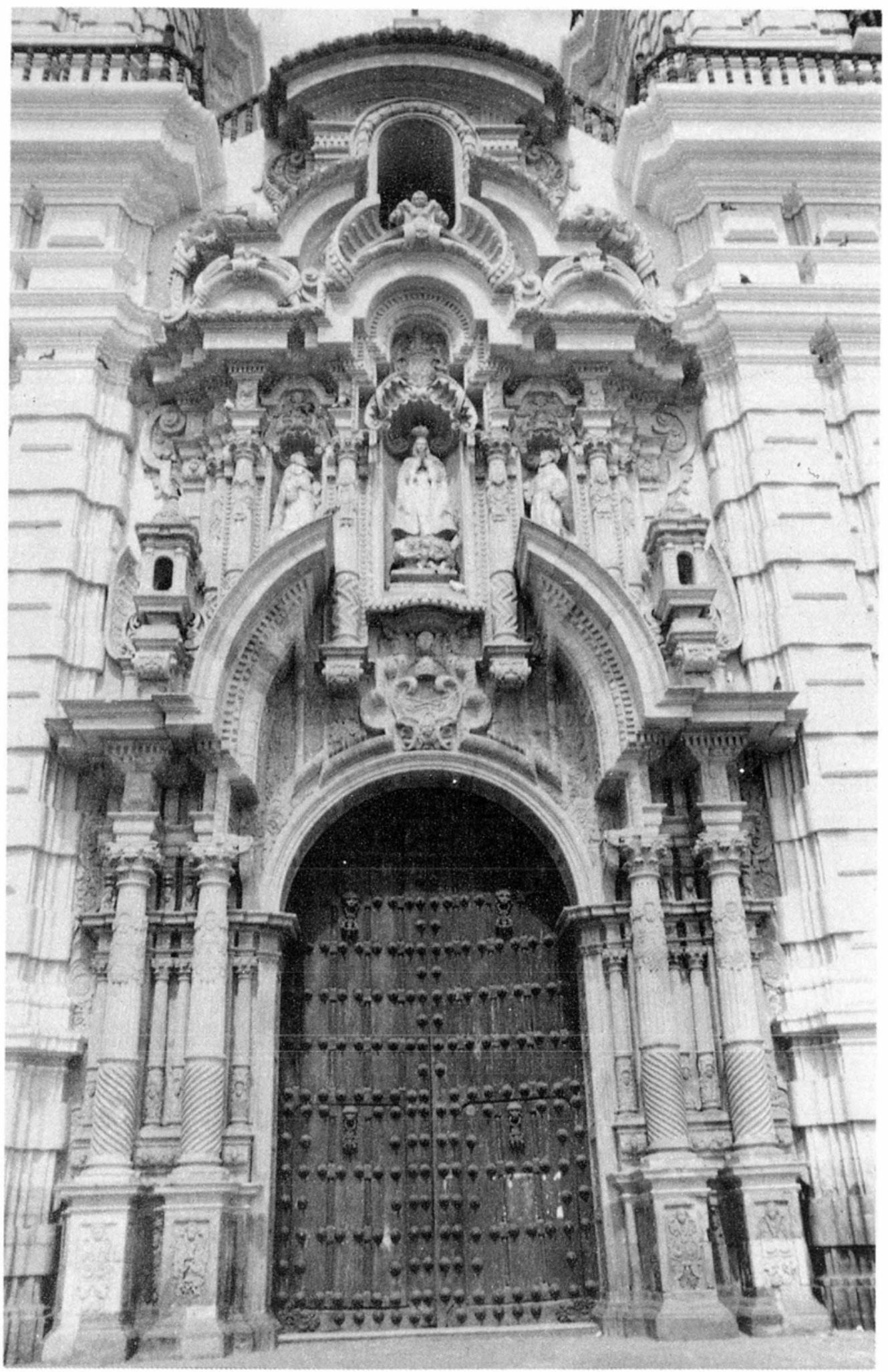

1. Constantino de Vasconcelos and Manuel de Escobar: Lima, San Francisco church frontispiece, 1657-74. 


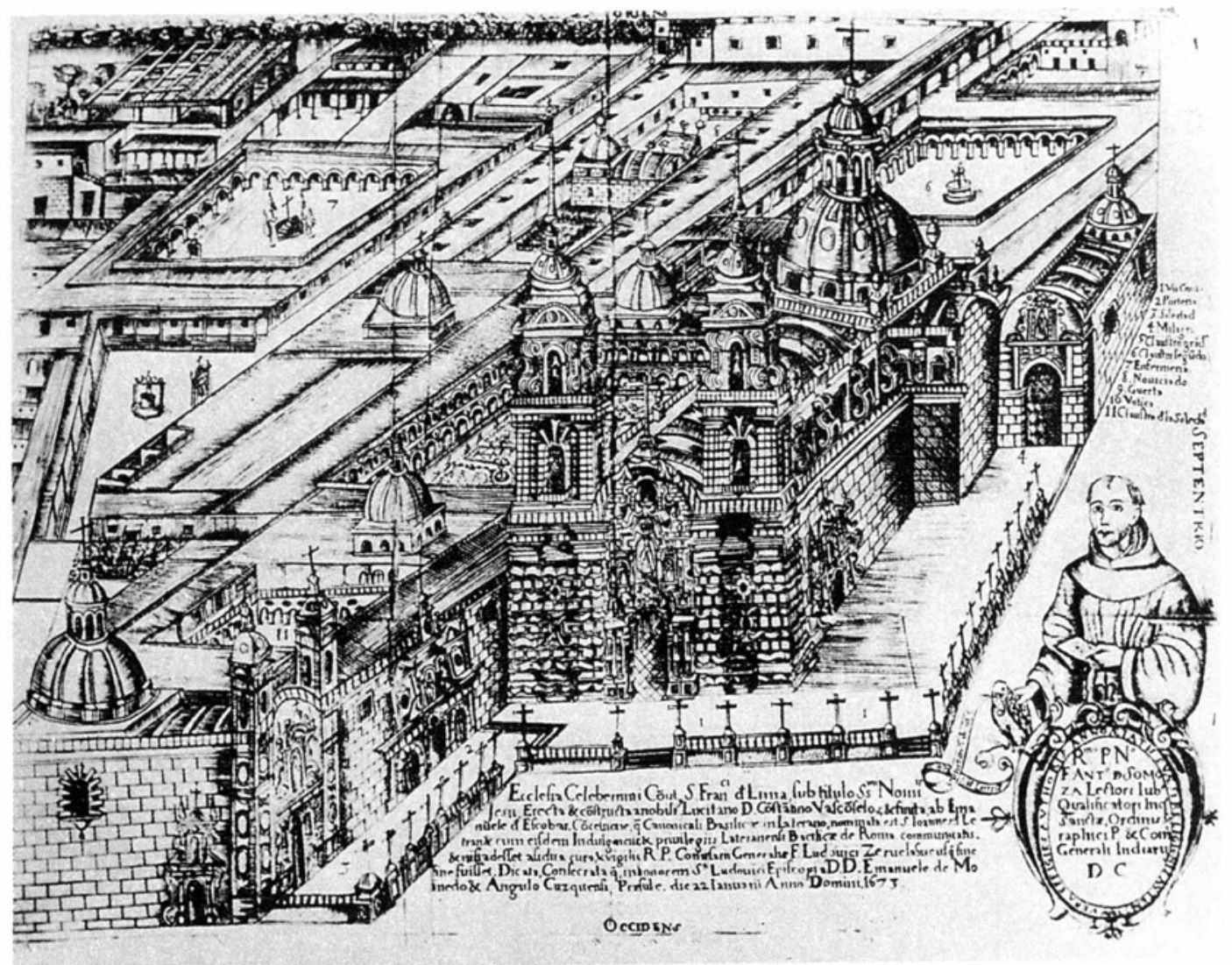

2. Juan de Benavides: Lima, San Francisco, perspective of the monastic complex in an engraving of c. 1674 (John Carter Brown Library, Brown University, Providence, R.I.). 
DOI: http://dx.doi.org/10.22201/iie.18703062e.1991.62.1598

3. Lima, San Francisco, west façade.

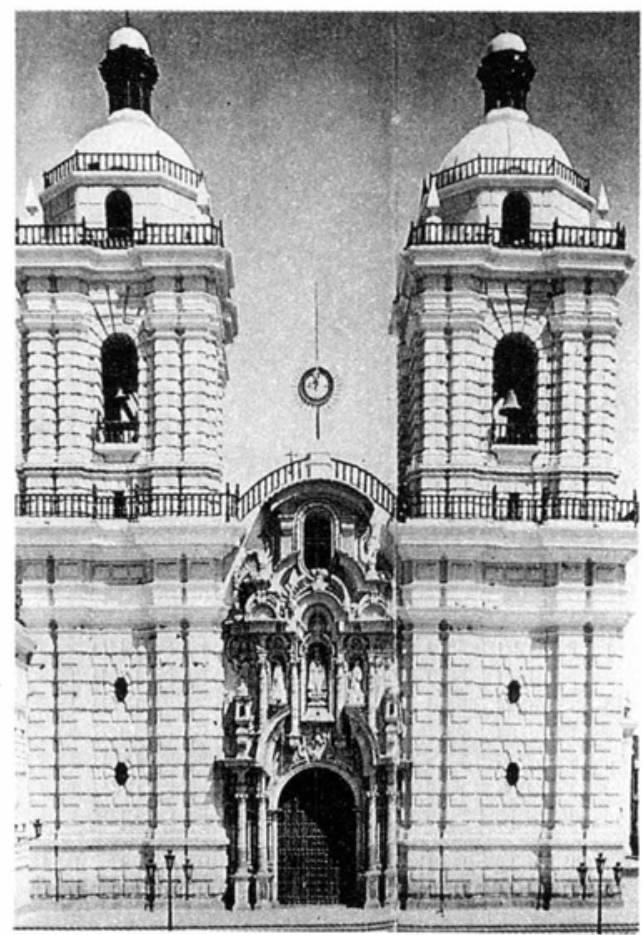

4. Lima, San Francisco, frontispiece detail.

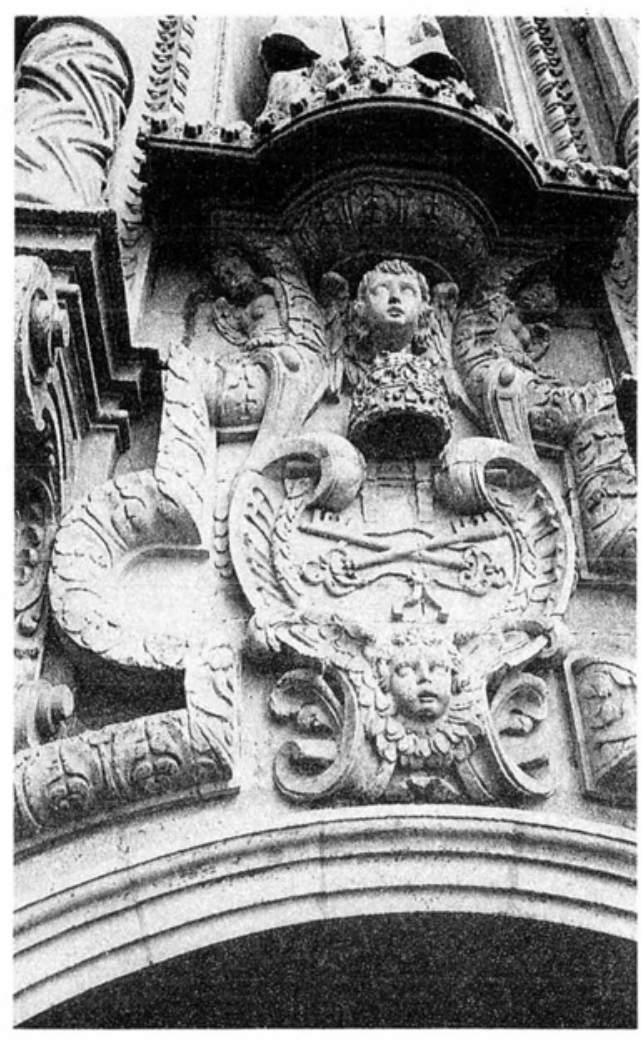




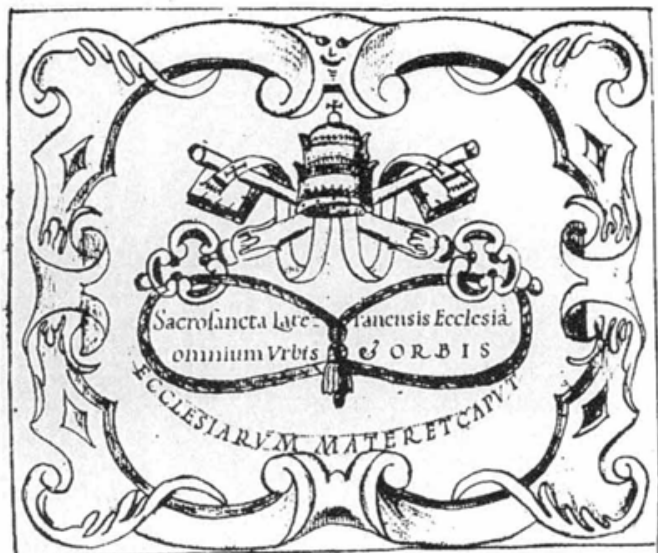

En dta Iglclia seg.ma Indulgencia P'lenaria Perpe: nu rameas quantas veces secintrare enclla a Rezar

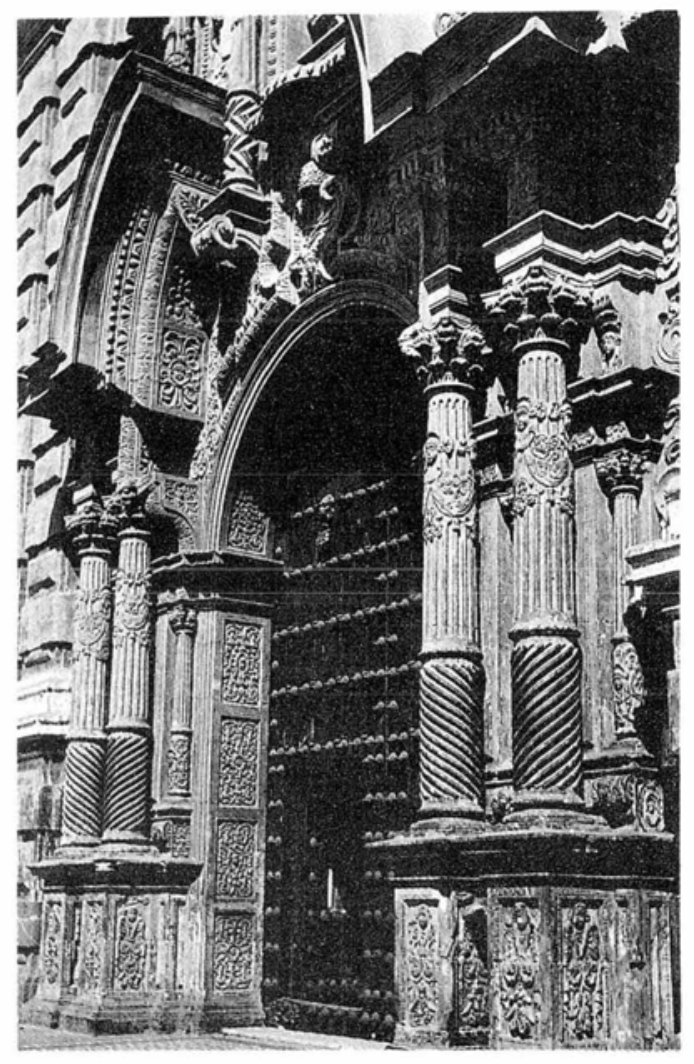

5. Coat of Arms of Pope Clement X in a drawing c. 1670 sent to Lima from Rome to be carved on the San Francisco frontispiece (Archives of San Francisco, Lima).
6. Lima, San Francisco, frontispiece lower portion. 
7. Lima, San Francisco, frontispiece central portion.

8. Lima, San Francisco, frontispiece upper portion.
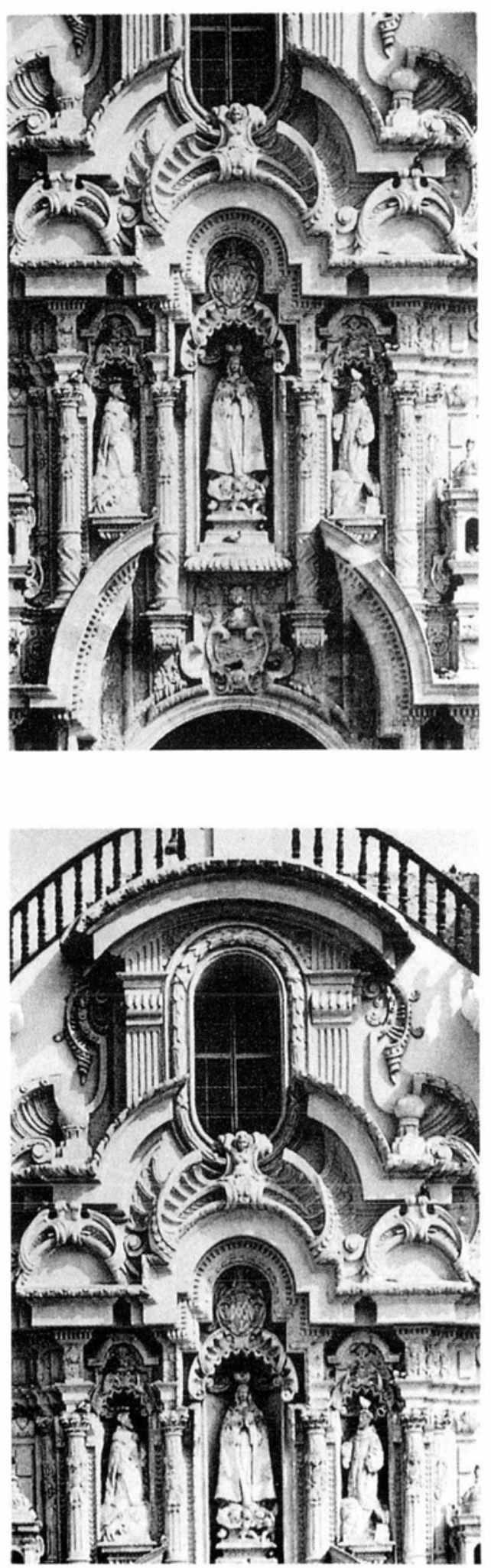


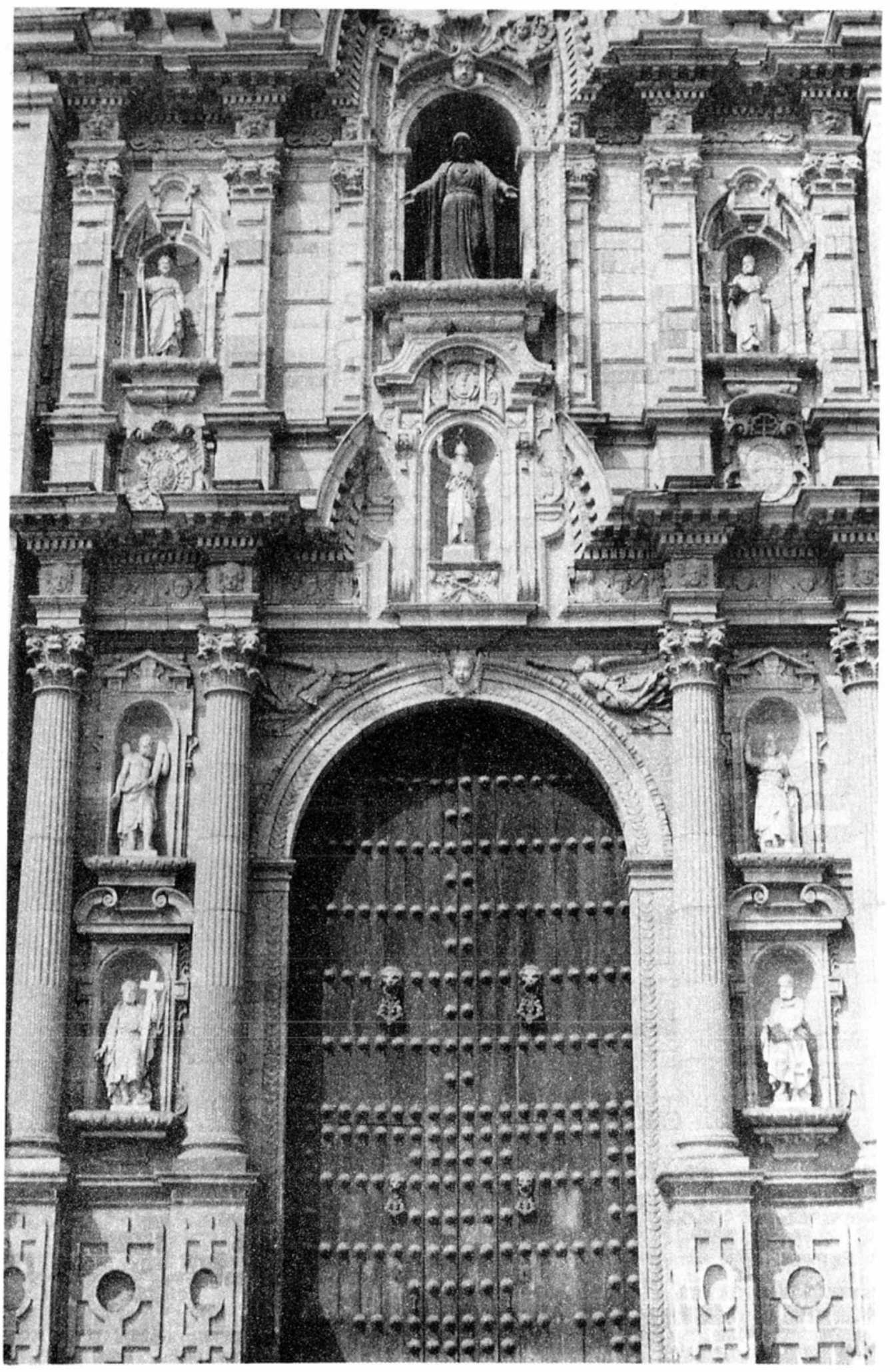

9. Juan Martínez de Arrona, Pedro de Noguera, et. al.: Lima, Cathedral, frontispiece, 1626-1722. 
DOI: http://dx.doi.org/10.22201/iie.18703062e.1991.62.1598

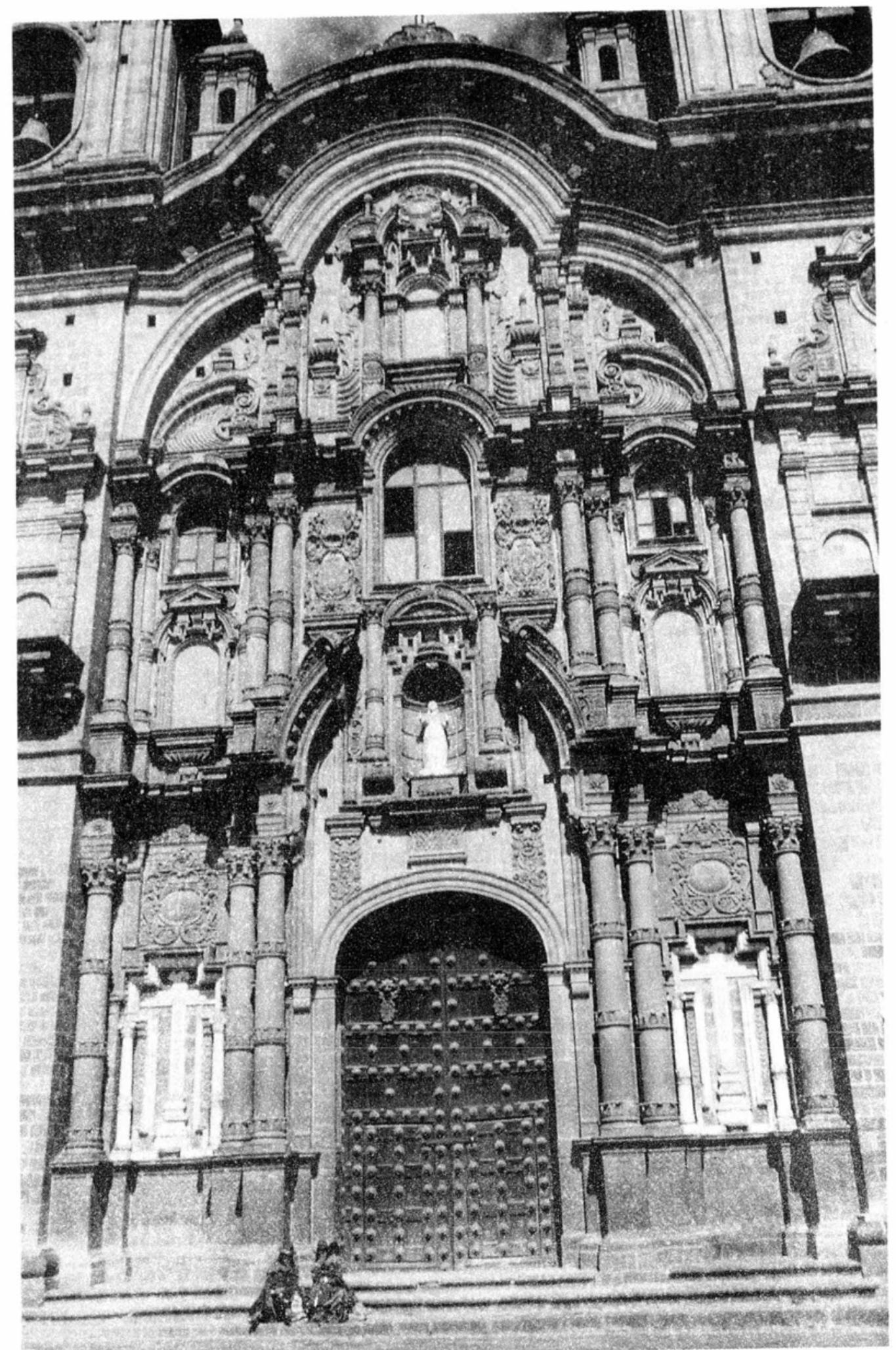

10. Juan Bautista Egidiano and Diego Martínez de Oviedo: Cuzco, La Compañía, frontispiece, 1664. 

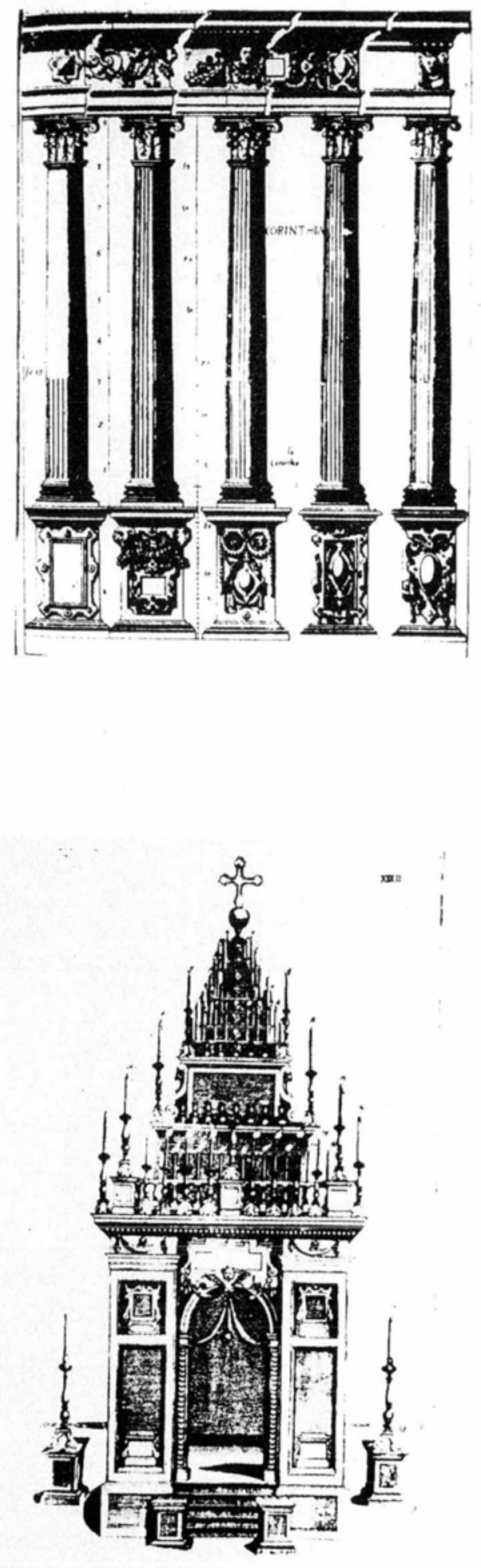

11. Johannes Vredeman Vries: Corinthian Order from Architectura (Antwerpie, 1581-98).
12. G.B. Vignola: Design for a funerary monument from Regola delli cinque Ordini d'Architettura (Amsterdam, 1642). 
DOI: http://dx.doi.org/10.22201/iie.18703062e.1991.62.1598

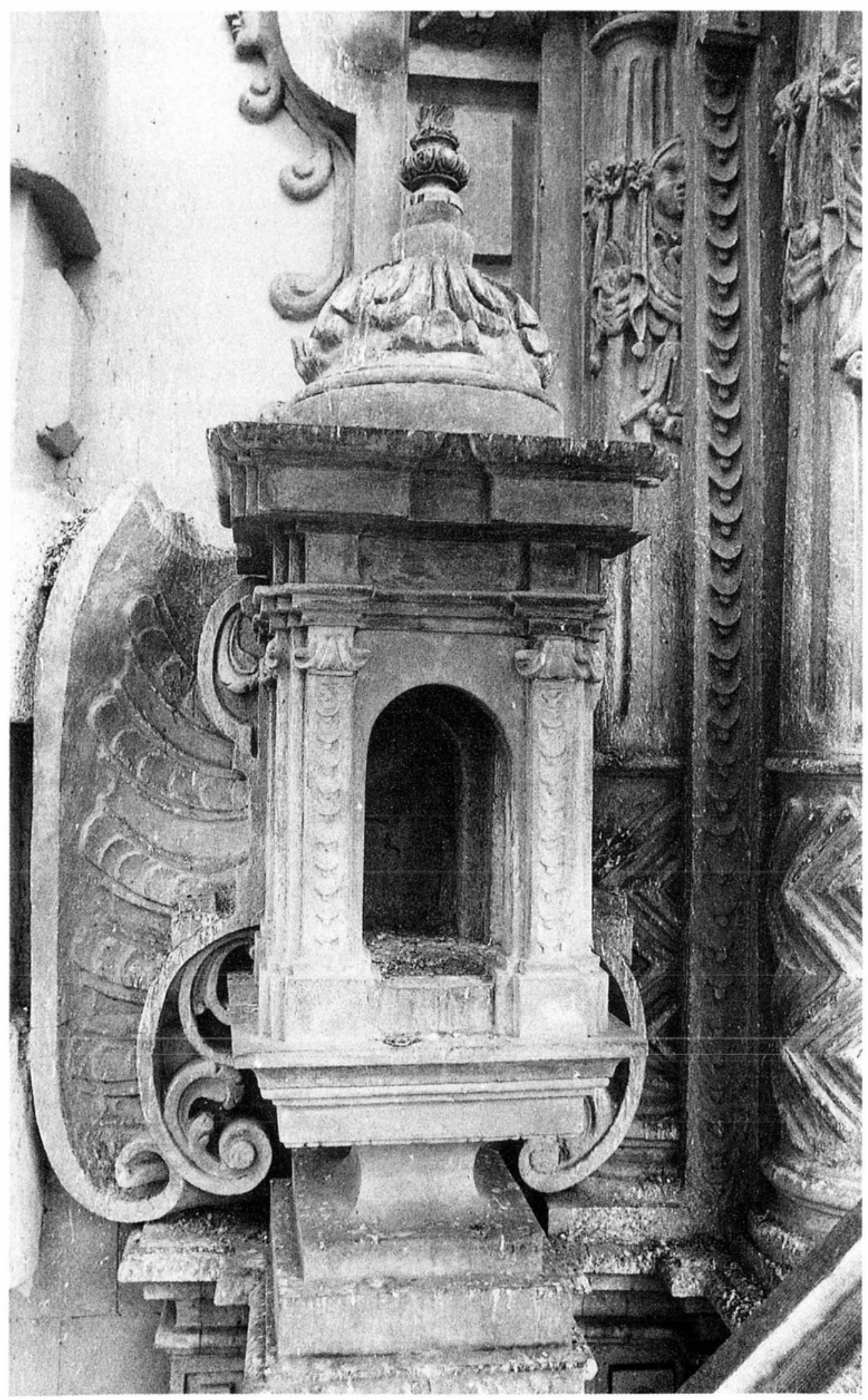

13. Lima, San Francisco, frontispiece detail. 

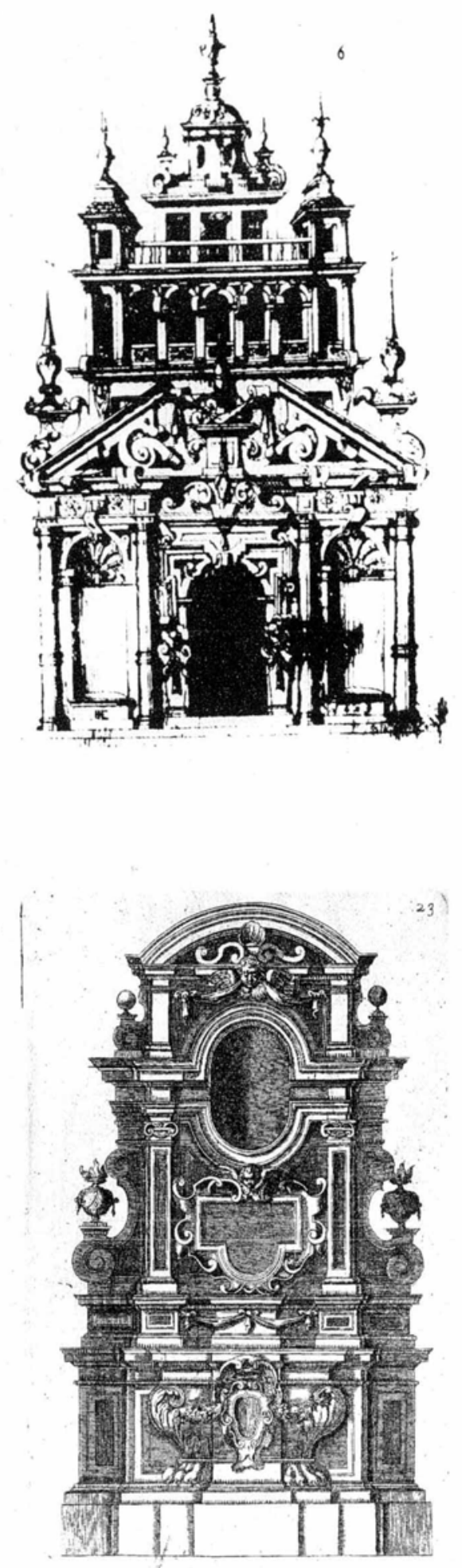

14. Jacques Francquart: Architectural design dated 1609 from Premier Livre d'Architecture (Bruxelles, 1627).

15. Bernardino Radi: Design for a tomb from Varie Inventioni per Depositi (Roma, 1618). 


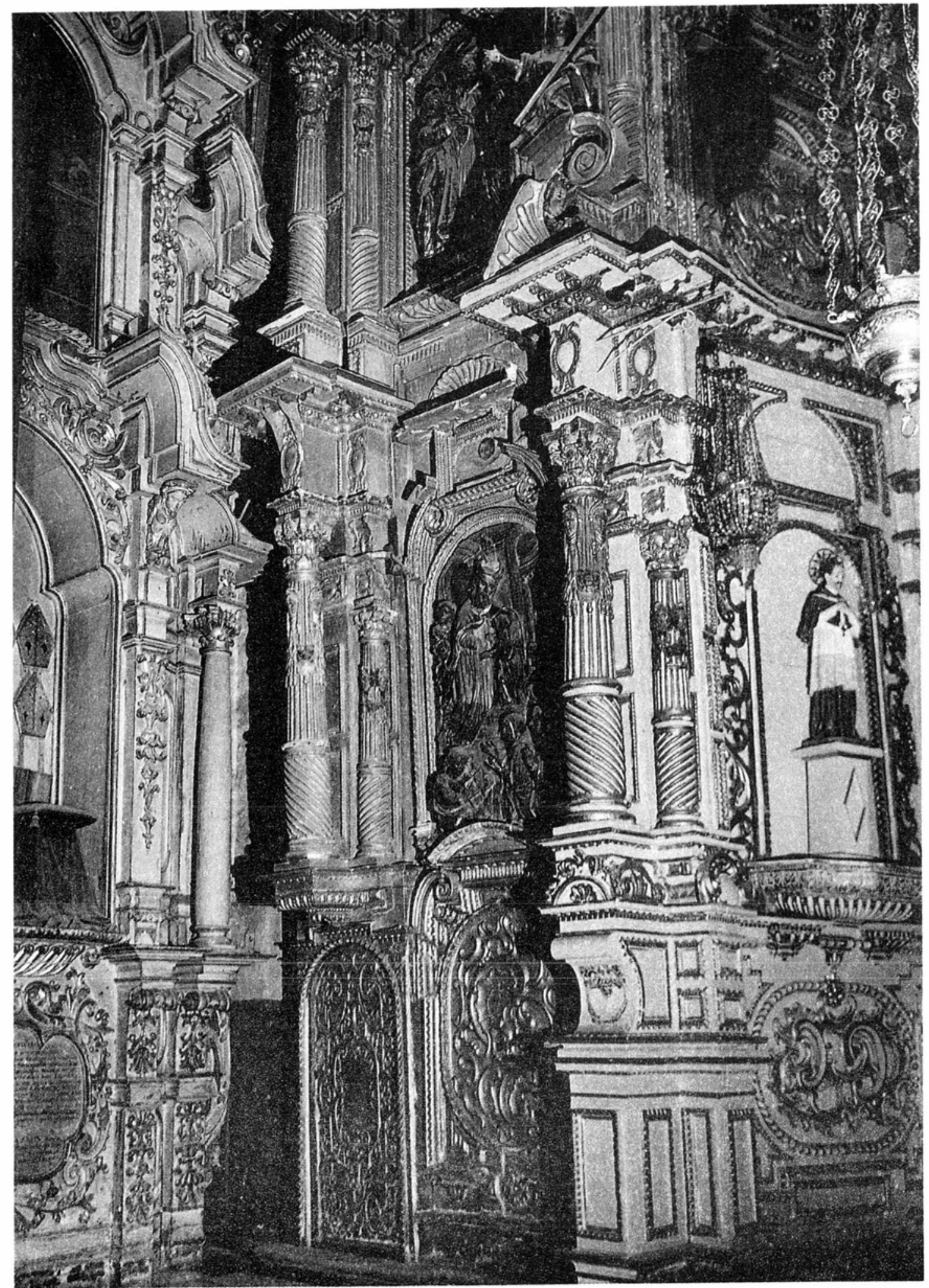

16. Lima, Cathedral, Immaculate Conception retablo, c. 1656; restored by Diego de Aguirre, 1692-97. 


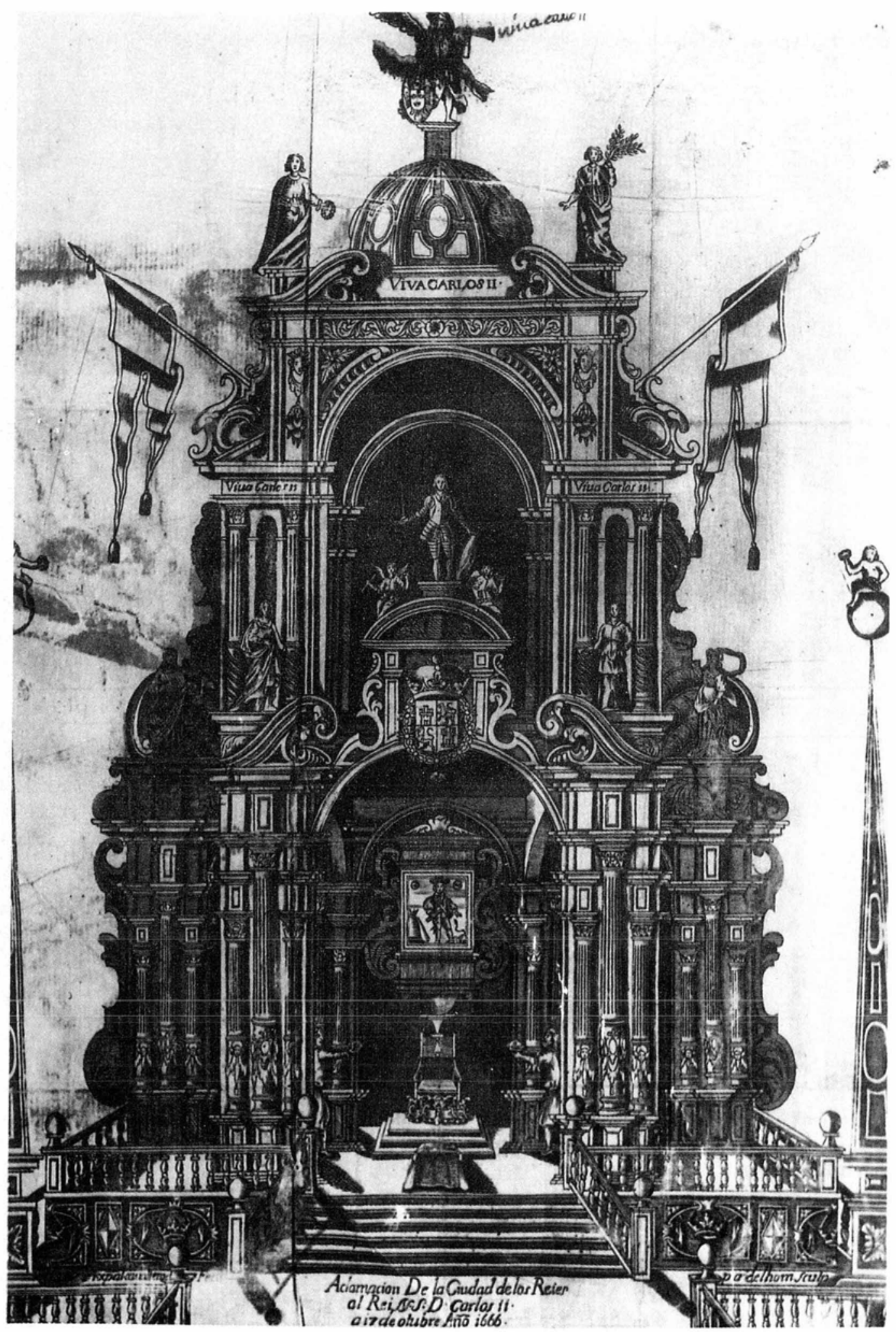

17. Cristóbal Caballero: Monument celebrating King Charles II of Spain erected in Lima in 1666 (after an engraving by P.A. Delhom). 


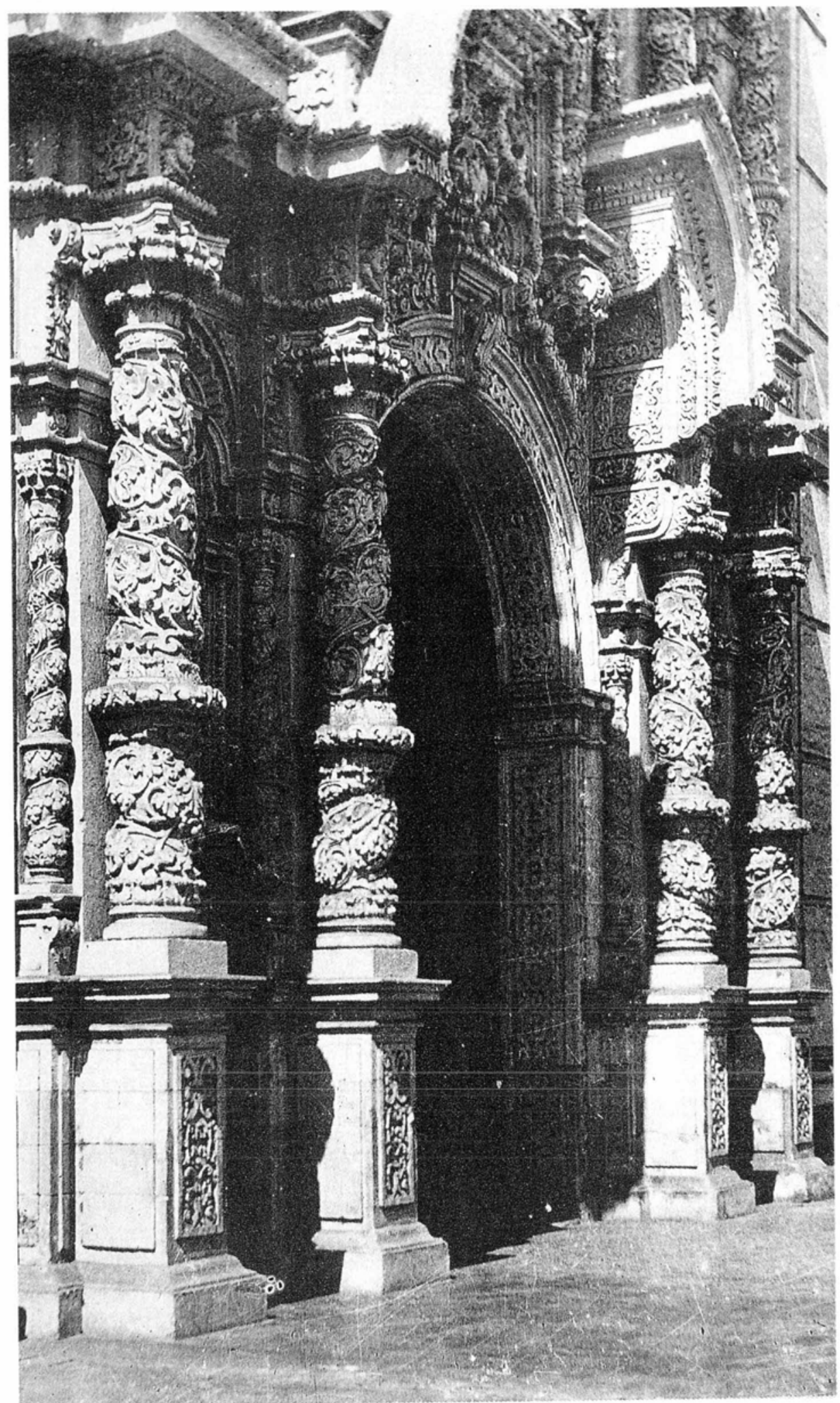

18. Lima, San Agustín, frontispiece lower portion, 1720 (photo: L.A. Rozas). 
DOI: http://dx.doi.org/10.22201/iie.18703062e.1991.62.1598

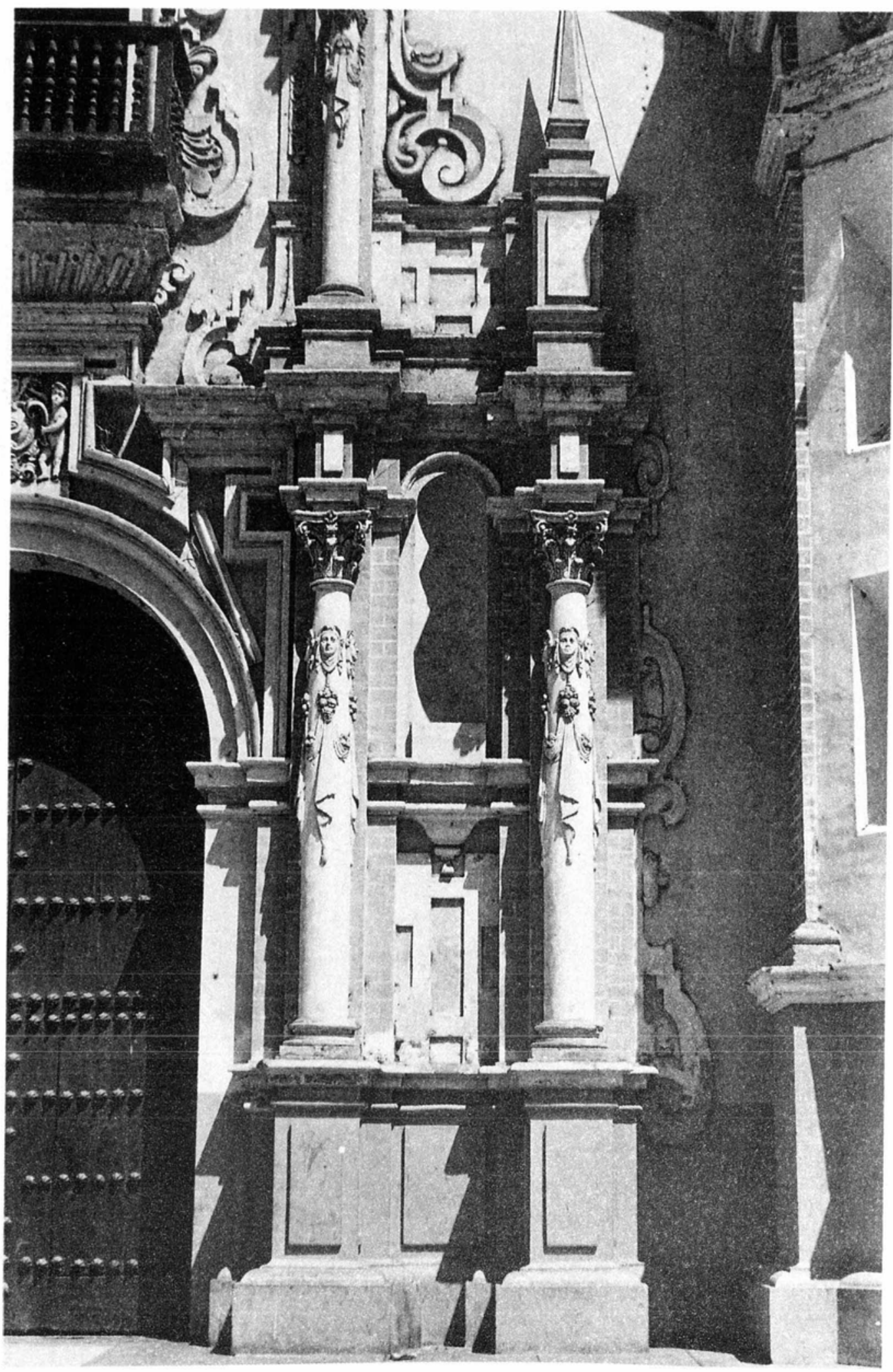

19. Ferreñafe, Lambayeque, Santa Lucía, frontispiece detail, c. 1684-90. 


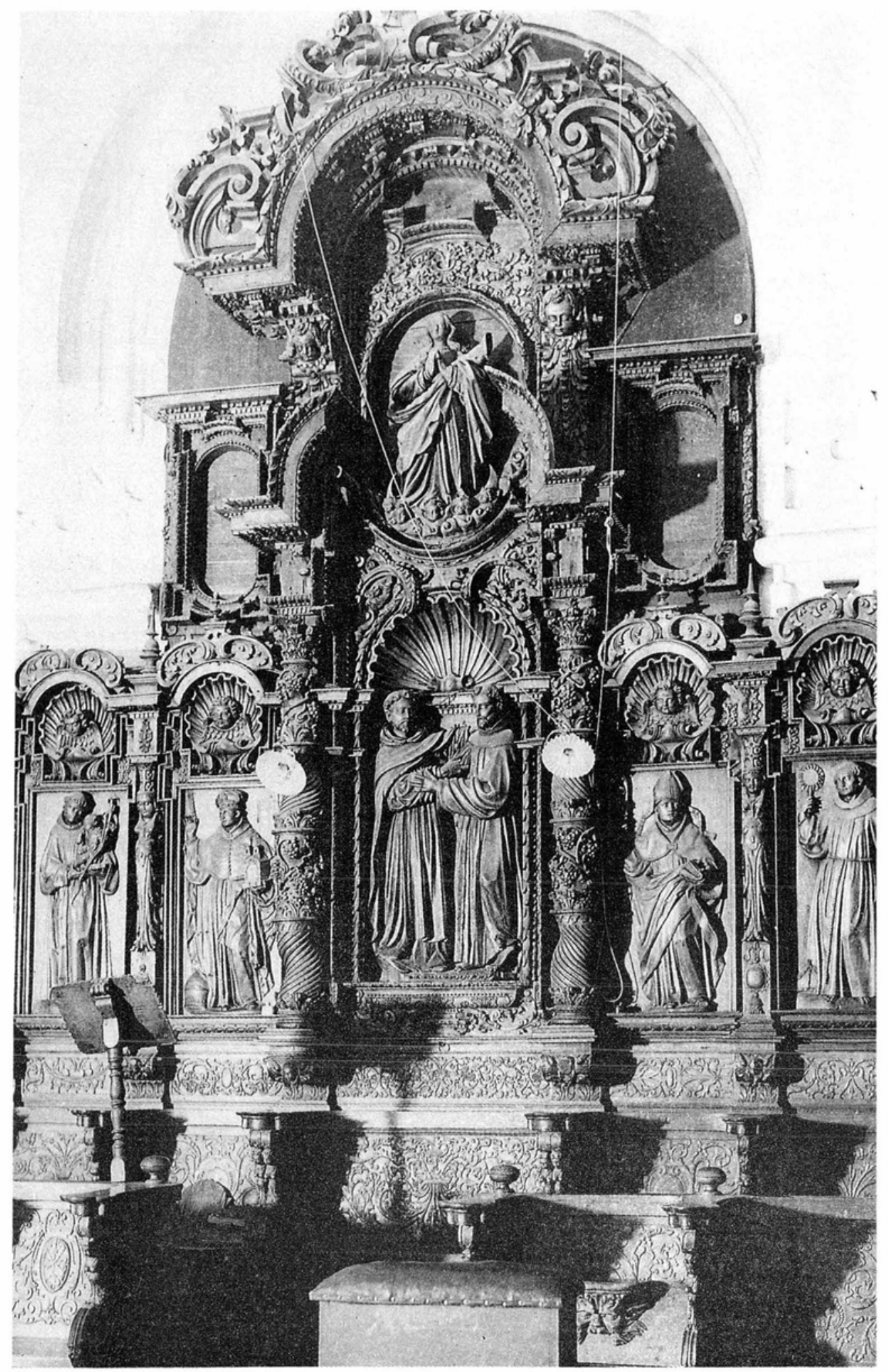

20. Lima, San Francisco, choir stalls and bishop's throne, c. 1674 (photo:

A. Guillén). 


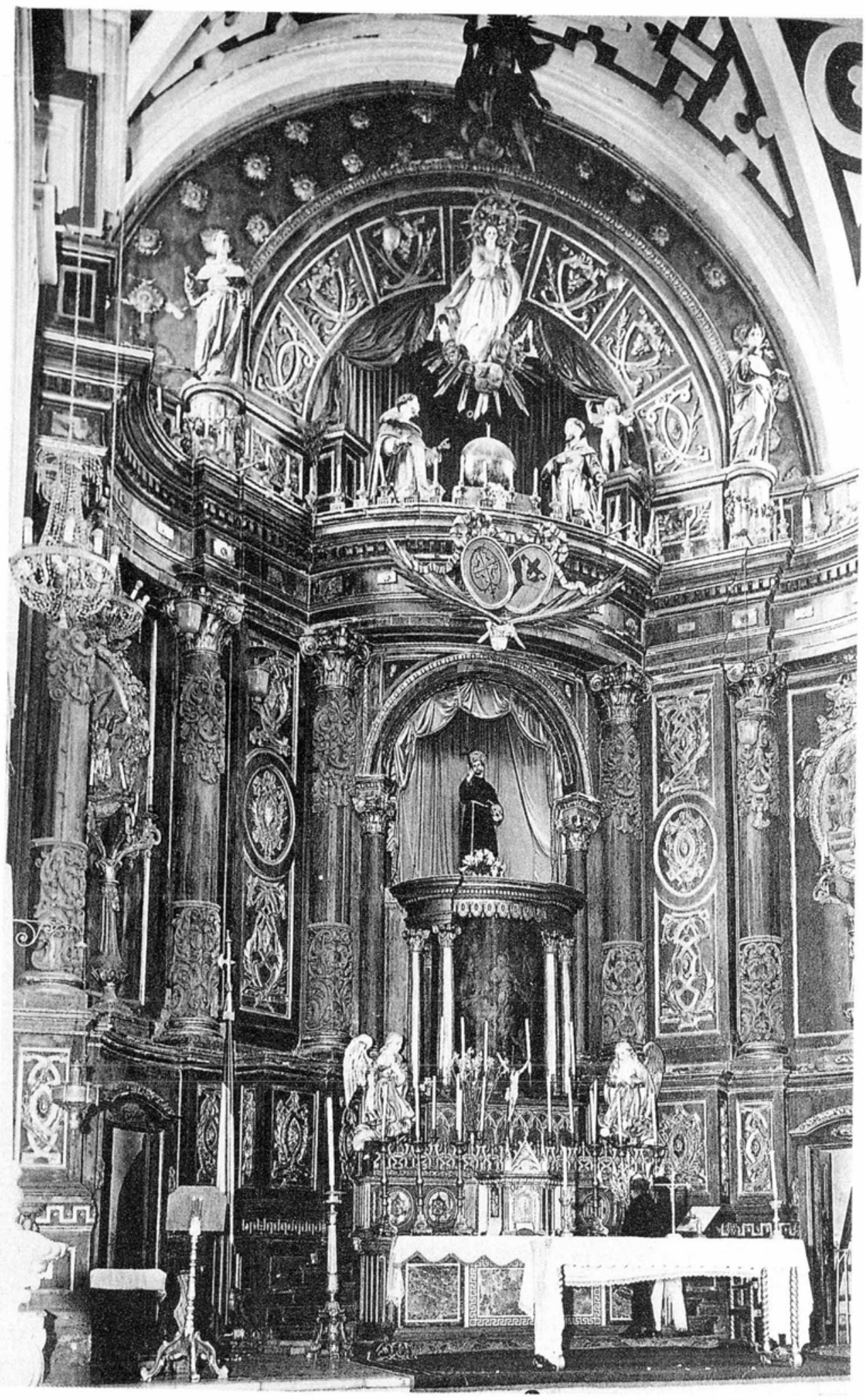

21. Matías Maestro: Lima, San Francisco, main altar retablo, 1805, as remodelled during the present century. 